\title{
Marinobacter mobilis sp. nov. and Marinobacter zhejiangensis sp. nov., halophilic bacteria isolated from the East China Sea
}

\author{
Correspondence \\ Xue-Wei Xu \\ xuxw@sio.org.cn \\ Min Wu \\ wumin@zju.edu.cn
}

\author{
Ying-Yi Huo, ${ }^{1}$ Chun-Sheng Wang, ${ }^{2,3}$ Jun-Yi Yang, ${ }^{2,3} \mathrm{Min} \mathrm{Wu}^{1}$ \\ and $\mathrm{Xue}-\mathrm{Wei} \mathrm{Xu}^{2,3}$ \\ ${ }^{1}$ College of Life Sciences, Zhejiang University, Hangzhou 310058, PR China \\ ${ }^{2}$ Laboratory of Marine Ecosystem and Biogeochemistry, State Oceanic Administration, Hangzhou \\ 310012, PR China \\ ${ }^{3}$ Second Institute of Oceanography, State Oceanic Administration, Hangzhou 310012, PR China
}

Three Gram-negative, aerobic, motile, halophilic, rod-shaped strains $\left(\mathrm{CN} 46^{\top}, \mathrm{CN} 71\right.$ and $\left.\mathrm{CN} 74^{\top}\right)$ were isolated from sediment of the East China Sea and subjected to a polyphasic taxonomic study. Strains $C N 46^{\top}$ and CN71 had identical $16 \mathrm{~S}$ rRNA gene sequences and phenotypic characteristics. Strain $\mathrm{CN} 46^{\top}$ was moderately halophilic. Growth of strain $\mathrm{CN} 46^{\top}$ was observed between 0.5 and $10.0 \%(\mathrm{w} / \mathrm{v}) \mathrm{NaCl}$ (optimal growth at 3.0-5.0\%) and between $\mathrm{pH} 6.5$ and 9.0. Strain $\mathrm{CN} 74^{\top}$ grew over a wider range of $\mathrm{pH}(\mathrm{pH}$ 6.0-9.5); the optimum $\mathrm{NaCl}$ concentration for growth was $1.0-3.0 \%$. The major fatty acids of strain $C N 46^{\top}$ were $C_{16: 1} \omega 9 c, C_{16: 0}$ and $C_{12: 0}$, whereas strain $C N 74^{\top}$ contained $\mathrm{C}_{16: 0}, \mathrm{C}_{16: 1} \omega 9 c, \mathrm{C}_{18: 1} \omega 9 \mathrm{c}$ and $\mathrm{C}_{12: 0}$. The DNA G+C contents of the three isolates were between 58.0 and 58.9 mol\%. Phylogenetic analyses based on $16 \mathrm{~S}$ rRNA gene sequences showed that strains $\mathrm{CN} 46^{\top}, \mathrm{CN} 71$ and $\mathrm{CN} 74^{\top}$ grouped together within the cluster of Marinobacter species. 16S rRNA gene sequence similarities of the three strains with the type strains of Marinobacter species ranged from 94.0 to $97.1 \%$. The DNA-DNA hybridization values of strain $C N 74^{\top}$ with strains $C N 46^{\top}$ and $C N 71$ were 35.0 and $36.0 \%$, respectively. Levels of DNA-DNA relatedness between strains $\mathrm{CN}{ }^{\top}{ }^{\top}$ and $\mathrm{CN} 74^{\top}$ and Marinobacter pelagius CGMCC $1.6775^{\top}$, Marinobacter gudaonensis CGMCC $1.6294^{\top}$ and Marinobacter koreensis DSM $17924^{\top}$ were $15.3-45.2 \%$. The results of DNA-DNA hybridizations, fatty acid analysis, and physiological and biochemical tests allowed genotypic and phenotypic differentiation of the isolates from closely related species. Two novel species are proposed, named Marinobacter mobilis sp. nov. (type strain $\mathrm{CN} 46^{\top}=\mathrm{CGMCC} 1.7059^{\top}=\mathrm{JCM}$ $15154^{\top}$ ) and Marinobacter zhejiangensis sp. nov. (type strain CN74 ${ }^{\top}=$ CGMCC $1.7061^{\top}=\mathrm{JCM}$ $\left.15156^{\top}\right)$.
The genus Marinobacter, which belongs to the family Alteromonadaceae, class Gammaproteobacteria, was first proposed by Gauthier et al. (1992) to accommodate aerobic, halophilic, rod-shaped bacteria that are capable of degrading a variety of hydrocarbons. The type species, Marinobacter hydrocarbonoclasticus, was isolated from seawater near a petroleum refinery. Over the past few years, a further 19 Marinobacter species have been described (Euzéby, 1997). Most of them have been isolated from saline environments,

The GenBank/EMBL/DDBJ accession numbers for the 16S rRNA gene sequences of strains CN71, CN46 ${ }^{\top}$ and $\mathrm{CN}^{\top} 4^{\top}$ are EU293411EU293413, respectively.

Transmission electron micrographs and detailed fatty acid compositions are available as supplementary material with the online version of this paper. including seawater (Yoon et al., 2003, 2004; Shivaji et al., 2005), marine sediment (Gorshkova et al., 2003; Romanenko et al., 2005; Guo et al., 2007), saline soil (Martín et al., 2003; Gu et al., 2007), sea sand (Kim et al., 2006), a brine-seawater interface (Antunes et al., 2007), a coastal hot spring (Shieh et al., 2003) and a wastewater pond (Liebgott et al., 2006), although some have been isolated from animal tissue (Romanenko et al., 2005) and algae (Green et al., 2006). Three strains, $\mathrm{CN} 46^{\mathrm{T}}, \mathrm{CN} 71$ and $\mathrm{CN} 74^{\mathrm{T}}$, were isolated from sediment of the East China Sea. The aim of this study was to determine whether these isolates represent novel species within the genus Marinobacter by a polyphasic approach.

The sediment sample was collected by a multicorer from

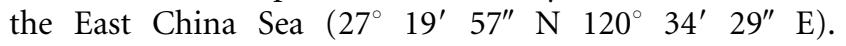


Approximately $100 \mathrm{mg}$ sample was suspended in $3 \mathrm{ml}$ sterile seawater and vortexed for $15 \mathrm{~min}$. The dispersed sediment suspension was diluted and added to modified ZoBell medium (ZoBell, 1941). The modified ZoBell medium contained (per 1 distilled water): $19.45 \mathrm{~g} \mathrm{NaCl}$, $8.8 \mathrm{~g} \mathrm{MgCl}_{2}, 3.24 \mathrm{~g} \mathrm{Na}_{2} \mathrm{SO}_{4}, 1.8 \mathrm{~g} \mathrm{CaCl}_{2}, 0.55 \mathrm{~g} \mathrm{KCl}$, $0.16 \mathrm{~g} \mathrm{NaHCO}_{3}, 0.1 \mathrm{~g}$ ferric citrate, $0.08 \mathrm{~g} \mathrm{KBr}, 34 \mathrm{mg}$ $\mathrm{CsCl}_{2}, 22 \mathrm{mg} \mathrm{H}_{3} \mathrm{BO}_{3}, 4.0 \mathrm{mg} \mathrm{Na}_{2} \mathrm{SiO}_{3}, 2.4 \mathrm{mg} \mathrm{NaF}, 1.6 \mathrm{mg}$ $\mathrm{NH}_{4} \mathrm{NO}_{3}, 8.0 \mathrm{mg} \mathrm{Na} \mathrm{PO}_{4}, 0.5 \mathrm{~g}$ peptone (Difco) and $0.1 \mathrm{~g}$ yeast extract (Difco); pH 7.4. After 3 days of aerobic incubation at $25{ }^{\circ} \mathrm{C}$, three colonies, named $\mathrm{CN} 46^{\mathrm{T}}$, CN74 and $\mathrm{CN} 74^{\mathrm{T}}$, were picked. All strains were purified by repeated restreaking and maintained on halophilic medium (HM) (Ventosa et al., 1982) at $30{ }^{\circ} \mathrm{C}$. The HM medium contained (per 1 distilled water): $40.0 \mathrm{~g} \mathrm{NaCl}, 2.0 \mathrm{~g} \mathrm{KCl}$, $1.0 \mathrm{~g} \mathrm{MgSO}_{4}, 0.36 \mathrm{~g} \mathrm{CaCl}_{2} .2 \mathrm{H}_{2} \mathrm{O}, 0.23 \mathrm{~g} \mathrm{NaBr}, 0.06 \mathrm{~g}$ $\mathrm{NaHCO}_{3}$, trace $\mathrm{FeCl}_{3}, 10.0$ g yeast extract (Difco), $5.0 \mathrm{~g}$ peptone (Difco), 1.0 g glucose; pH 7.2.

The optimal conditions for growth were determined in HM with different salt concentrations $(0,0.5,1,3,5,7.5$, $10,15$ and $20 \%, \mathrm{w} / \mathrm{v})$. The $\mathrm{pH}$ range for growth was determined by adding MES ( $\mathrm{pH}$ 5.0-6.0), PIPES ( $\mathrm{pH}$ 6.57.0), Tricine ( $\mathrm{pH} 7.5-8.5)$, CAPSO (pH 9.0-9.5) or CAPS ( $\mathrm{pH} 10.0-10.5)$ to $\mathrm{HM}$ at a concentration of $40 \mathrm{mM}$. The temperature range for growth was determined by incubating cultures at $4-48{ }^{\circ} \mathrm{C}$. Cell morphology and motility were examined by optical microscopy (Olympus BX40) and transmission electron microscopy (JEM-1230). Strains $\mathrm{CN} 46^{\mathrm{T}}$ and $\mathrm{CN} 74^{\mathrm{T}}$ were motile by a polar flagellum (see Supplementary Fig. S1 available in IJSEM Online).

Physiological and biochemical characteristics were determined using previously described methods (Xu et al., 2008; Mata et al., 2002). Susceptibility to antibiotics was detected on HM plates by using antibiotic discs containing the following: amoxicillin $(10 \mu \mathrm{g})$, ampicillin $(10 \mu \mathrm{g})$, bacitracin $(0.04 \mathrm{IU})$, carbenicillin $(100 \mu \mathrm{g})$, cefoxitin $(30 \mu \mathrm{g})$, ceftriaxone $(30 \mu \mathrm{g})$, chloramphenicol $(30 \mu \mathrm{g})$, erythromycin $(15 \mu \mathrm{g})$, nitrofurantoin $(300 \mu \mathrm{g})$, novobiocin $(30 \mu \mathrm{g})$, nystatin $(100 \mu \mathrm{g})$, penicillin $(10 \mu \mathrm{g})$, polymyxin B (300 IU), streptomycin $(10 \mu \mathrm{g})$, tobramycin $(10 \mu \mathrm{g})$ and tetracycline $(30 \mu \mathrm{g})$. Detailed results are given in the species descriptions.

Fatty acid methyl esters, prepared from lipids that had been extracted from cells grown in $\mathrm{HM}$ plates for $48 \mathrm{~h}$ at $30{ }^{\circ} \mathrm{C}$, were analysed by using GC-MS (Kuykendall et al., 1988). Genomic DNA G + C contents were determined by thermal denaturation $\left(T_{\mathrm{m}}\right)$ (Marmur \& Doty, 1962) using Escherichia coli K-12 DNA as a calibration standard.

The $16 \mathrm{~S}$ rRNA gene was amplified and analysed as described previously (Xu et al., 2007). PCR products were cloned into a pMD18-T vector (TaKaRa) and then sequenced to determine the almost-complete 16S rRNA gene sequence. The sequences were compared with those of closely related reference organisms from the FASTA network service.

Sequence data were aligned with CLUSTAL W 1.8 (Thompson et al., 1994). Phylogenetic trees were constructed by the neighbour-joining (Saitou \& Nei, 1987) and maximumparsimony (Fitch, 1971) methods with the MEGA3 program package (Kumar et al., 2004) and by the maximumlikelihood method (Felsenstein, 1981) with the PHYLIP 3.6 program. Evolutionary distances were calculated according to the algorithm of Kimura's two-parameter model (Kimura, 1980) for the neighbour-joining method.

Colony morphology and pigmentation of the isolates were observed following growth on HM agar and milk HM agar (HM agar supplemented with $1 \%$ skimmed milk) for $48 \mathrm{~h}$ at $30{ }^{\circ} \mathrm{C}$. Strain $\mathrm{CN} 74^{\mathrm{T}}$ was semitransparent and creamcoloured; strains $\mathrm{CN} 46^{\mathrm{T}}$ and $\mathrm{CN} 71$, however, were transparent and non-pigmented. When the incubation time was extended to 14 days, colonies of strain $\mathrm{CN} 46^{\mathrm{T}}$ became cream. Cells of strains $\mathrm{CN} 74^{\mathrm{T}}$ and $\mathrm{CN} 46^{\mathrm{T}}$ were cultivated under identical conditions for comparison of the cellular fatty acid content. The major fatty acids $(>5 \%)$ of strain $\mathrm{CN} 46^{\mathrm{T}}$ were $\mathrm{C}_{16: 1} \omega 9 c, \mathrm{C}_{16: 0}$ and $\mathrm{C}_{12: 0}$, whereas strain $\mathrm{CN}^{\mathrm{T}} 4^{\mathrm{T}}$ contained $\mathrm{C}_{16: 0}, \mathrm{C}_{16: 1} \omega 9 c, \mathrm{C}_{18: 1} \omega 9 c$ and $\mathrm{C}_{12: 0}$. A more detailed fatty acid composition is given in Supplementary Table S1. In addition, strain $\mathrm{CN} 46^{\mathrm{T}}$ could be distinguished from strain $\mathrm{CN} 74^{\mathrm{T}}$ by $\mathrm{pH}$ range for growth, hydrolysis of lecithin and utilization of ethanol. The three isolates could also be differentiated from Marinobacter species with validly published names by some phenotypic and genotypic characteristics, such as salinity and temperature ranges for growth, hydrolysis of substrates, utilization of some hydrocarbons and DNA $\mathrm{G}+\mathrm{C}$ content (Table 1).

$16 \mathrm{~S}$ rRNA gene sequence similarities between the isolates and the type strains of Marinobacter species ranged from 94.0 to $97.1 \%$. Strains $\mathrm{CN} 6^{\mathrm{T}}$ and CN71 had identical $16 \mathrm{~S}$ rRNA gene sequences. Strain $\mathrm{CN} 46^{\mathrm{T}}$ showed the highest sequence similarities to $\mathrm{CN} 74^{\mathrm{T}}(97.8 \%)$ and the type strains of Marinobacter pelagius (97.1\%) and Marinobacter gudaonensis $(97.1 \%)$; sequence similarities between strain $\mathrm{CN} 46^{\mathrm{T}}$ and the type strains of other Marinobacter species were less than $97.0 \%$. 16S rRNA gene sequence similarities between strain CN74 ${ }^{\mathrm{T}}$ and the type strains of Marinobacter species were below $96.5 \%$. The phylogenetic trees indicated that strains $\mathrm{CN} 46^{\mathrm{T}}, \mathrm{CN} 71$ and $\mathrm{CN} 74^{\mathrm{T}}$ clustered together in a distinct branch within the genus Marinobacter (Fig. 1).

To verify the species status of the two novel Marinobacter species, DNA-DNA hybridizations were performed by the thermal denaturation and renaturation method of De Ley et al. (1970) as modified by Huß et al. (1983), using a Beckman DU 800 spectrophotometer. The tests were carried out in triplicate. The DNA-DNA hybridization values of strain $\mathrm{CN} 74^{\mathrm{T}}$ with $\mathrm{CN} 46^{\mathrm{T}}$ and $\mathrm{CN} 71$ were 35.0 and $36.0 \%$, respectively. DNA-DNA hybridization values between strain $\mathrm{CN} 46^{\mathrm{T}}$ and M. pelagius CGMCC $1.6775^{\mathrm{T}}$, M. gudaonensis CGMCC $1.6294^{\mathrm{T}}$ and M. koreensis DSM $17924^{\mathrm{T}}$ were $32.6,45.2$ and $37.0 \%$, respectively. The DNADNA hybridization values of strain $\mathrm{CN} 74^{\mathrm{T}}$ to $M$. pelagius CGMCC $1.6775^{\mathrm{T}}$, M. gudaonensis CGMCC $1.6294^{\mathrm{T}}$ and $M$. koreensis DSM $17924^{\mathrm{T}}$ were $15.3,32.5$ and $31.0 \%$, 
Table 1. Differential phenotypic characteristics of strains $C N 46^{\top}$ and $\mathrm{CN} 74^{\top}$ and the type strains of related Marinobacter species

Strains: 1, CN46 ${ }^{\mathrm{T}}$; 2, CN74 ${ }^{\mathrm{T}}$; 3, M. pelagius CGMCC 1.6775 ${ }^{\mathrm{T}}$; 4, M. koreensis DSM 17924 ${ }^{\mathrm{T}}$; 5, M. gudaonensis CGMCC 1.6294 ${ }^{\mathrm{T}}$; 6, M. lutaoensis $\mathrm{T}_{5054^{\mathrm{T}}}$; 7, M. bryozoorum KMM 3840 ${ }^{\mathrm{T}} ; 8$, M. hydrocarbonoclasticus ATCC $49840^{\mathrm{T}}$. Data are based on our comparative studies with M. pelagius CGMCC $1.6775^{\mathrm{T}}$, M. koreensis DSM $17924^{\mathrm{T}}$ and M. gudaonensis CGMCC 1.6294 ${ }^{\mathrm{T}}$, as well as on literature data derived from Gauthier et al. (1992), Shieh et al. (2003), Romanenko et al. (2005), Kim et al. (2006), Gu et al. (2007) and Xu et al. (2008). +, Positive; -, negative; (+) weakly positive; ND, no data. All taxa are positive for motility, oxidase and catalase.

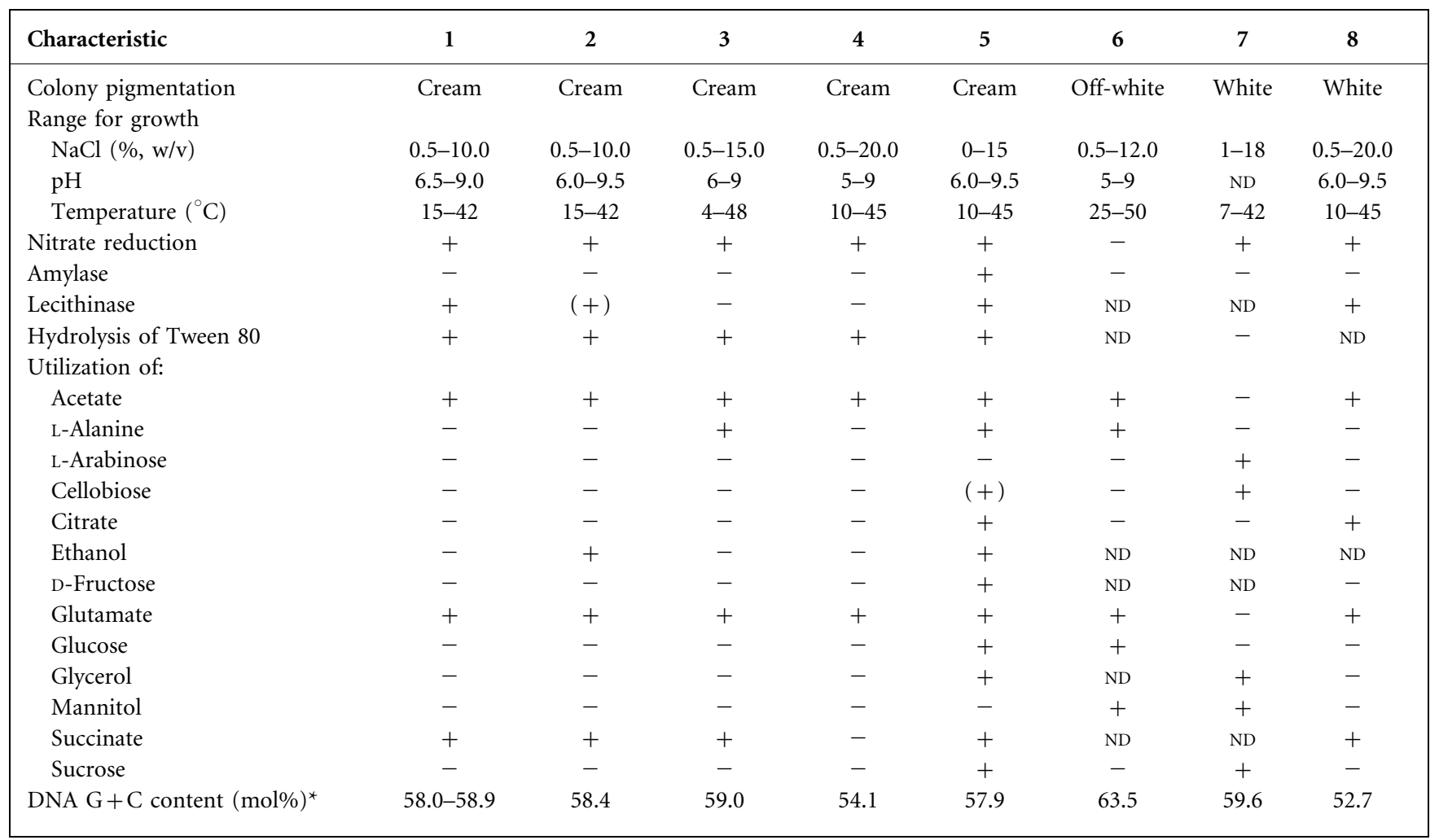

${ }^{\star}$ All values were determined using the $T_{\mathrm{m}}$ method except that of M. koreensis DSM $17924^{\mathrm{T}}$, which was determined by HPLC.

respectively. All the values are sufficiently low to classify strains $\mathrm{CN}_{4}{ }^{\mathrm{T}}$ and $\mathrm{CN}_{4}{ }^{\mathrm{T}}$ as representatives of two genotypically distinct species within the genus Marinobacter.

Based on differential phenotypic properties, as well as $16 \mathrm{~S}$ rRNA gene sequence analysis and DNA-DNA hybridization data, it is concluded that strains $\mathrm{CN} 46^{\mathrm{T}}$ and CN74 ${ }^{\mathrm{T}}$ represent two novel species within the genus Marinobacter.

\section{Description of Marinobacter mobilis sp. nov.}

Marinobacter mobilis (mo'bi.lis. L. masc. adj. mobilis motile).

Cells are Gram-negative and motile by a polar flagellum. Young cultures show rod-like cells $(1.5-3.0 \times 0.5-0.8 \mu \mathrm{m})$. Colonies on HM agar are 1-2 $\mathrm{mm}$ in diameter, circular, smooth, elevated, transparent and non-pigmented after $48 \mathrm{~h}$ at $30{ }^{\circ} \mathrm{C}$. Moderately halophilic. No growth occurs in the absence of salt. Growth occurs at $\mathrm{NaCl}$ concentrations of $0.5-10.0 \%(\mathrm{w} / \mathrm{v})$, with optimum growth at $3.0-5.0 \%$. Grows at $\mathrm{pH}$ 6.5-9.0 and $15-42{ }^{\circ} \mathrm{C}$ (optimum growth at pH 7.0-7.5 and $30-35{ }^{\circ} \mathrm{C}$ ). Oxidase- and catalase-positive.
Nitrate is reduced. Tweens 20 and 80 are hydrolysed. Aesculin, casein, DNA, gelatin, starch and tyrosine are not hydrolysed. Lecithinase-positive. Negative for gluconate oxidation, indole production, $o$-nitrophenyl- $\beta$-D-galactopyranosidase and urease. $\mathrm{H}_{2} \mathrm{~S}$ is produced from thiosulfate. The following substrates are utilized for growth: acetate, glutamate, L-isoleucine, lactate, malate, propionate, pyruvate, succinate and L-valine. The following compounds are not utilized as sole carbon sources: L-alanine, Larabinose, L-arginine, cellobiose, citrate, L-cysteine, ethanol, formate, D-fructose, fumarate, D-galactose, gluconate, glucose, glycerol, glycine, L-histidine, myo-inositol, lactose, lysine, malonate, maltose, mannitol, D-mannose, L-methionine, raffinose, rhamnose, ribose, L-serine, sorbitol, Lsorbose, sucrose, trehalose, tyrosine and D-xylose. Acid is not produced from L-arabinose, D-fructose, D-galactose, glucose, myo-inositol, lactose, maltose, mannitol, D-mannose, rhamnose, sorbitol, L-sorbose, trehalose or sucrose. Susceptible to amoxicillin, ampicillin, carbenicillin, cefoxitin, ceftriaxone, chloramphenicol, erythromycin, nitrofurantoin, novobiocin, penicillin, polymyxin $\mathrm{B}$, tobramycin 


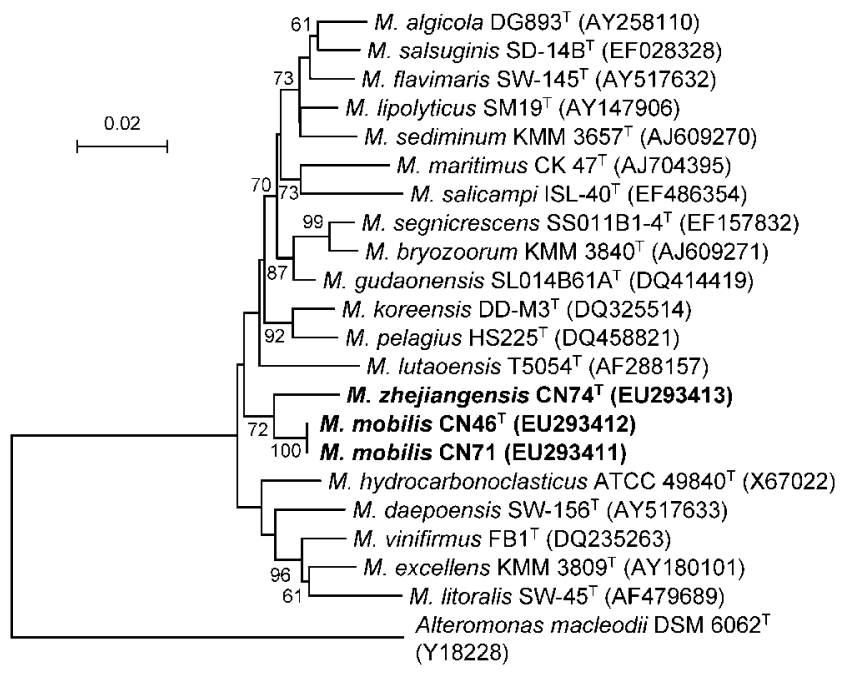

Fig. 1. Neighbour-joining tree based on 16S rRNA gene sequences showing the phylogenetic relationship between the isolates and related taxa. Bootstrap percentages are based on 1000 replicates; only values $>60 \%$ are shown. Bar, 0.02 substitutions per nucleotide position.

and tetracycline, but not to bacitracin, nystatin or streptomycin. Major fatty acids are $\mathrm{C}_{16: 1} \omega 9 c, \mathrm{C}_{16: 0}$ and $\mathrm{C}_{12: 0}$. The DNA G+C content is $58.0-58.9 \mathrm{~mol} \%\left(T_{\mathrm{m}}\right)$.

The type strain is $\mathrm{CN}^{2} 6^{\mathrm{T}}\left(=\mathrm{CGMCC} 1.7059^{\mathrm{T}}=\mathrm{JCM}\right.$ $\left.15154^{\mathrm{T}}\right)$, isolated from a marine sediment sample, Zhejiang, China. Strain CN71, a reference strain, was isolated from the same source.

\section{Description of Marinobacter zhejiangensis sp. nov.}

Marinobacter zhejiangensis (zhe.ji.ang.en'sis. N.L. masc. adj. zhejiangensis pertaining to Zhejiang province in China, where the type strain was isolated).

Cells are Gram-negative and motile. Young cultures show rod-like cells $(1.0-2.5 \times 0.4-0.8 \mu \mathrm{m})$, occurring singly or in pairs. Colonies on HM agar are $2-3 \mathrm{~mm}$ in diameter, circular and slightly irregular, elevated, semitransparent and creamcoloured after $48 \mathrm{~h}$ at $30{ }^{\circ} \mathrm{C}$. No growth occurs in the absence of salt. Growth occurs at $\mathrm{NaCl}$ concentrations of $0.5-$ $10.0 \%(\mathrm{w} / \mathrm{v})$, with optimum growth at $1.0-3.0 \%$. Grows at $\mathrm{pH} 6.0-9.5$ and $15-42{ }^{\circ} \mathrm{C}$ (optimum growth at $\mathrm{pH}$ 7.0-7.5 and $30-35{ }^{\circ} \mathrm{C}$ ). Oxidase- and catalase-positive. Nitrate is reduced. Tweens 20 and 80 are hydrolysed. Aesculin, casein, DNA, gelatin, starch and tyrosine are not hydrolysed. Weakly positive for lecithinase. Negative for gluconate oxidation, indole production, $o$-nitrophenyl- $\beta$-D-galactopyranosidase and urease. $\mathrm{H}_{2} \mathrm{~S}$ is produced from thiosulfate. The following substrates are utilized for growth: acetate, ethanol, glutamate, L-isoleucine, lactate, malate, propionate, pyruvate, succinate and L-valine. The following compounds are not utilized as sole carbon sources: L-alanine, L-arabinose, L-arginine, cellobiose, citrate, L-cysteine, formate, D-fructose, fumarate, D-galactose, gluconate, glucose, glycerol, glycine, L-histidine, myo-inositol, lactose, lysine, malonate, maltose, mannitol, Dmannose, L-methionine, raffinose, rhamnose, ribose, Lserine, sorbitol, L-sorbose, sucrose, trehalose, tyrosine and D-xylose. Acid is not produced from L-arabinose, D-fructose, D-galactose, glucose, myo-inositol, lactose, maltose, mannitol, D-mannose, rhamnose, sorbitol, L-sorbose, trehalose or sucrose. Susceptible to amoxicillin, ampicillin, carbenicillin, cefoxitin, ceftriaxone, chloramphenicol, erythromycin, nitrofurantoin, novobiocin, penicillin, polymyxin $\mathrm{B}$, tobramycin and tetracycline, but not to bacitracin, nystatin or streptomycin. Major fatty acids are $\mathrm{C}_{16: 0}, \mathrm{C}_{16: 1} \omega 9 c, \mathrm{C}_{18: 1} \omega 9 c$ and $\mathrm{C}_{12: 0}$.

The type strain is $\mathrm{CN} 74^{\mathrm{T}}\left(=\mathrm{CGMCC} 1.7061^{\mathrm{T}}=\mathrm{JCM}\right.$ $15156^{\mathrm{T}}$ ), isolated from a marine sediment sample of Zhejiang, China. The DNA G+C content of the type strain is $58.4 \pm 0.1 \mathrm{~mol} \%\left(T_{\mathrm{m}}\right)$.

\section{Acknowledgements}

This work was supported by grants from the Major State Basic Research Development Program of China (973 Program) (2004CB719604-3), the Chinese Offshore Investigation and Assessment (908-ZC-I-02) and the Scientific Research Fund of the Second Institute of Oceanography, SOA (JT0709).

\section{References}

Antunes, A., França, L., Rainey, F. A., Huber, R., Nobre, M. F., Edwards, K. J. \& da Costa, M. S. (2007). Marinobacter salsuginis sp. nov., isolated from the brine-seawater interface of the Shaban Deep, Red Sea. Int J Syst Evol Microbiol 57, 1035-1040.

De Ley, J., Cattoir, H. \& Reynaerts, A. (1970). The quantitative measurement of DNA hybridization from renaturation rates. Eur $J$ Biochem 12, 133-142.

Euzéby, J. P. (1997). List of Bacterial Names with Standing in Nomenclature: a folder available on the Internet. Int J Syst Bacteriol 47, 590-592. http://www.bacterio.cict.fr

Felsenstein, J. (1981). Evolutionary trees from DNA sequences: a maximum likelihood approach. J Mol Evol 17, 368-376.

Fitch, W. M. (1971). Toward defining the course of evolution: minimum change for a specific tree topology. Syst Zool 20, 406-416.

Gauthier, M. J., Lafay, B., Christen, R., Fernandez, L., Acquaviva, M., Bonin, P. \& Bertrand, J. C. (1992). Marinobacter hydrocarbonoclasticus gen. nov., sp. nov., a new, extremely halotolerant, hydrocarbondegrading marine bacterium. Int J Syst Bacteriol 42, 568-576.

Gorshkova, N. M., Ivanova, E. P., Sergeev, A. F., Zhukova, N. V., Alexeeva, Y., Wright, J. P., Nicolau, D. V., Mikhailov, V. V. \& Christen, R. (2003). Marinobacter excellens sp. nov., isolated from sediments of the Sea of Japan. Int J Syst Evol Microbiol 53, 2073-2078.

Green, D. H., Bowman, J. P., Smith, E. A., Gutierrez, T. \& Bolch, C. J. S. (2006). Marinobacter algicola sp. nov., isolated from laboratory cultures of paralytic shellfish toxin-producing dinoflagellates. Int $J$ Syst Evol Microbiol 56, 523-527.

Gu, J., Cai, H., Yu, S.-L., Qu, R., Yin, B., Guo, Y.-F., Zhao, J.-Y. \& Wu, X.-L. (2007). Marinobacter gudaonensis sp. nov., isolated from an oilpolluted saline soil in a Chinese oilfield. Int J Syst Evol Microbiol 57, 250-254. 
Guo, B., Gu, J., Ye, Y.-G., Tang, Y.-O., Kida, K. \& Wu, X.-L. (2007). Marinobacter segnicrescens sp. nov., a moderate halophile isolated from benthic sediment of the South China Sea. Int J Syst Evol Microbiol 57, 1970-1974.

Huß, V. A. R., Festl, H. \& Schleifer, K. H. (1983). Studies on the spectrophotometric determination of DNA hybridization from renaturation rates. Syst Appl Microbiol 4, 184-192.

Kim, B. Y., Weon, H. Y., Yoo, S. H., Kim, J. S., Kwon, S. W., Stackebrandt, E. \& Go, S. J. (2006). Marinobacter koreensis sp. nov., isolated from sea sand in Korea. Int J Syst Evol Microbiol 56, 26532656.

Kimura, M. (1980). A simple method for estimating evolutionary rates of base substitutions through comparative studies of nucleotide sequences. J Mol Evol 16, 111-120.

Kumar, S., Tamura, K. \& Nei, M. (2004). MEGA3: integrated software for molecular evolutionary genetics analysis and sequence alignment. Brief Bioinform 5, 150-163.

Kuykendall, L. D., Roy, M. A., O'Neill, J. J. \& Devine, T. E. (1988). Fatty acids, antibiotic resistance, and deoxyribonucleic acid homology groups of Bradyrhizobium japonicum. Int J Syst Bacteriol 38, 358-361.

Liebgott, P. P., Casalot, L., Paillard, S., Lorquin, J. \& Labat, M. (2006). Marinobacter vinifirmus sp. nov., a moderately halophilic bacterium isolated from a wine-barrel-decalcification wastewater. Int J Syst Evol Microbiol 56, 2511-2516.

Marmur, J. \& Doty, P. (1962). Determination of the base composition of deoxyribonucleic acid from its thermal denaturation temperature. $J$ Mol Biol 5, 109-118.

Martín, S., Márquez, M. C., Sánchez-Porro, C., Mellado, E., Arahal, D. R. \& Ventosa, A. (2003). Marinobacter lipolyticus sp. nov., a novel moderate halophile with lipolytic activity. Int J Syst Evol Microbiol 53, 1383-1387.

Mata, J. A., Martínez-Cánovas, J., Quesada, E. \& Béjar, V. (2002). A detailed phenotypic characterisation of the type strains of Halomonas species. Syst Appl Microbiol 25, 360-375.

Romanenko, L. A., Schumann, P., Rohde, M., Zhukova, N. V., Mikhailov, V. V. \& Stackebrandt, E. (2005). Marinobacter bryozoorum sp. nov. and Marinobacter sediminum sp. nov., novel bacteria from the marine environment. Int J Syst Evol Microbiol 55, 143-148.

Saitou, N. \& Nei, M. (1987). The neighbor-joining method: a new method for reconstructing phylogenetic trees. Mol Biol Evol 4, 406425.

Shieh, W. Y., Jean, W. D., Lin, Y. T. \& Tseng, M. (2003). Marinobacter lutaoensis sp. nov., a thermotolerant marine bacterium isolated from a coastal hot spring in Lutao, Taiwan. Can J Microbiol 49, 244-252.

Shivaji, S., Gupta, P., Chaturvedi, P., Suresh, K. \& Delille, D. (2005). Marinobacter maritimus sp. nov., a psychrotolerant strain isolated from sea water off the subantarctic Kerguelen islands. Int J Syst Evol Microbiol 55, 1453-1456.

Thompson, J. D., Higgins, D. G. \& Gibson, T. J. (1994). CLUSTAL W: improving the sensitivity of progressive multiple sequence alignment through sequence weighting, position-specific gap penalties and weight matrix choice. Nucleic Acids Res 22, 4673-4680.

Ventosa, A., Quesada, E., Rodriguez-Valera, F., Ruiz-Berraquero, F. \& Ramos-Cormenzana, A. (1982). Numerical taxonomy of moderately halophilic Gram-negative rods. J Gen Microbiol 128, 1959-1968.

Xu, X.-W., Wu, Y.-H., Zhou, Z., Wang, C.-S., Zhou, Y.-G., Zhang, H.-B., Wang, Y. \& Wu, M. (2007). Halomonas saccharevitans sp. nov., Halomonas arcis sp. nov. and Halomonas subterranea sp. nov., halophilic bacteria isolated from hypersaline environments of China. Int J Syst Evol Microbiol 57, 1619-1624.

Xu, X.-W., Wu, Y.-H., Wang, C.-S., Yang, J.-Y., Oren, A. \& Wu, M. (2008). Marinobacter pelagius sp. nov., a moderately halophilic bacterium. Int J Syst Evol Microbiol 58, 637-640.

Yoon, J. H., Shin, D. Y., Kim, I. G., Kang, K. H. \& Park, Y. H. (2003). Marinobacter litoralis sp. nov., a moderately halophilic bacterium isolated from sea water from the East Sea in Korea. Int J Syst Evol Microbiol 53, 563-568.

Yoon, J. H., Yeo, S. H., Kim, I. G. \& Oh, T. K. (2004). Marinobacter flavimaris sp. nov. and Marinobacter daepoensis sp. nov., slightly halophilic organisms isolated from sea water of the Yellow Sea in Korea. Int J Syst Evol Microbiol 54, 1799-1803.

ZoBell, C. E. (1941). Studies on marine bacteria. I. The cultural requirements of heterotrophic aerobes. J Mar Res 4, 42-75. 